\title{
INVESTIGATION OF PATERNITY ESTABLISHING WITHOUT THE PUTATIVE FATHER USING HYPERVARIABLE DNA PROBES
}

\author{
Tsuyoshi YokoI, Toru OdaIra, Masayuki Nata, \\ and Kaoru SAGISAKA \\ Department of Forensic Medicine, Tohoku University School of Medicine, \\ Aoba-ku, Sendai 980, Japan
}

\begin{abstract}
Summary Seven kinds of DNA probes which recognize hypervariable loci were applied for paternity test. The putative father was decreased and unavailable for the test. The two legitimate children and their mother (the deceased's wife) and the four illegitimate children and their mother (the deceased's kept mistress) were available for analysis. Paternity index of four illegitimate child was investigated. Allelic frequencies and their confidence intervals among unrelated Japanese individuals were previously reported from our laboratory, and co-dominant segregation of the polymorphism was confirmed in family studies. Cumulative paternity indices of four illegitimate children from 16 kinds of standard blood group markers were $165,42,0.09$, and 36 , respectively. On the other hand, cumulative paternity indices from 7 kinds of DNA probes are 2,363, 4,685, 57,678, and 54,994, respectively, which are 14,113,640,864, and 1,509 times higher than that from standard blood group markers. The DNA analyses gave nearly conclusive evidence that the putative father was the biological father of the children. Especially, the paternity relation of the third illegitimate child could not be established without the DNA analyses. Accordingly, DNA polymorphism is considered to be informative enough for paternity test.
\end{abstract}

Key Words hypervariable polymorphism, paternity test

\section{INTRODUCTION}

According to advances in hematogenetics field, the numerous number of blood group markers have been used in paternity test.

Recently, studies of DNA polymorphism are in progress, and many DNA restriction fragment length polymorphisms (RFLP), have been reported. Another

Received April 11, 1990; revised version received May 7, 1990; Accepted June 4, 1990. 
class of polymorphisms is hypervariable polymorphic regions of DNA resulting from a variable number of tandem repeats (VNTR). A common feature of many of these probes is the presence of a short core sequence element which is repeated in tandem along the chromosome and provides variable polymorphism of the locus (Nakamura et al., 1987; Odelberg et al., 1989). They are valuable genetic markers for human linkage maps (Nakamura et al., 1988a, b), parentage test (Jeffreys et al., 1985a; Baird et al., 1986; Allen et al., 1989) and individual identification (Giusti et al., 1986).

In the present study, seven kinds of hypervariable DNA probes were applied for a paternity test of the family in dispute. The putative father was decreased and unavailable for the test. Parentage relations of the four illegitimate children were not excluded by the tests of blood group markers. Paternity indices from DNA analyses were compared with standard blood group marker tests through statistical analyses.

\section{MATERIALS AND METHODS}

Case summary. This case was settled in the District Court of Miyagi Prefecture, in May 1989 involving a putative father who had died. The two legitimate children and their mother (the deceased's wife), the four illegitimate children and their mother (the deceased's kept mistress) were available for analysis. The pedigree of the family is shown in Fig. 1. The petition by their mother was to confirm the parentage relations on behalf of the four illegitimate children.

Sample and DNA probes. DNA samples were prepared from peripheral blood with the standard technique (Maniatis et al., 1982). Four of seven probes were purchased from Amersham, U.K. MR24/1 XY pseudoautosomal DNA probe (MR24/1) is assigned to the pseudoautosomal region at the telomers of $X$ and $Y$ chromosomes. Alpha-globin 3' DNA probe (3'globin) is located to 16p12 (Higgs et al., 1981). Ha-ras DNA probe (Ha-ras) is located to $11 \mathrm{p} 15.5$ (Capon et al., 1983) and mucin DNA probe (Mucin) is assigned to 1q21 (Gendler et al., 1987). The other three probes were kindly supplied from JCRB Gene Bank, Japan. D2S44 (probe pYNH24), D17S30 (probe pYNZ22) and D1S57 (probe pYNZ2) were

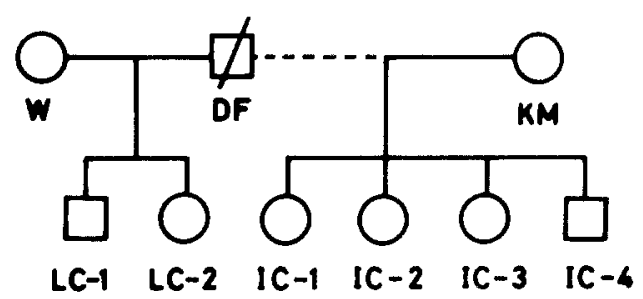

Fig. 1. A.lleged pedigree of the family. W, wife; DF, deceased father; KM, kept mistress; LC-1, LC-2, legitimate child 1 and 2 ; IC-1, IC-2, IC-3, IC-4, illegitimate child $1,2,3$, and 4 . -.-, alleged relationship; - , assumed relationship. 
originally developed by Nakamura et al. (1987). Chromosomal location of these probes is $2 \mathrm{q}, 17 \mathrm{p}$, and $1 \mathrm{p}$, respectively.

DNA hybridization. The probes were labeled with $\left[{ }^{32} \mathrm{P}\right] \alpha \mathrm{dCTP}(3,000 \mu \mathrm{Ci} /$ mmol) using a Multiprime DNA labeling system (Amersham, U.K.). Two kinds of size markers were used at the same time: (1) 123-base-pair ladder DNA (Bethesda Research Laboratories, U.S.A.) and (2) EcoT 14 fragments of lambda DNA (Takara, Japan). Five different restriction enzymes [REs, HinfI (Takara, Japan), MspI, PvuII, TaqI (Boehringer Mannheim, F.R.G.) and RsaI (New England Biolab., U.S.A.)] were used for digestion (2.5 $\mu \mathrm{g}$ of DNA/sample) and incubated at $37^{\circ} \mathrm{C}$ for $5 \mathrm{hr}$ using 12 RE units. Electrophoresis was carried out in $1 \times$ TBE buffer $(\mathrm{pH} 8.0)$ at $1 \mathrm{~V} / \mathrm{cm}$ of gel for approximately $20 \mathrm{hr}$. The size markers were loaded in triplicate on each gel; the two outside lanes on each side of the gel, and the center lanes. The DNA fragments were then transferred to a nylon membrane (Schleicher \& Schuell). Prehybridization and hybridization were carried out as described by Yokoi et al. (1990a). Autoradiography was carried out at $-90^{\circ} \mathrm{C}$ using Fuji X-ray film.

Standard paternity testing methods. Paternity testing methods are taken from standard protocols including serological analyses of red cell antigen systems (ABO, Rh-Hr, MNSs, Duffy, Kidd, and $\mathrm{P}_{1}$ ), red cell enzymes [phosphoglucomutase-1 (PG$\mathrm{M}_{1}$ ), esterase-D (EsD), acid phosphatase (AcP), phosphogluconate dehydrogenase (PGD)], serum proteins [transferrin (Tf), haptoglobin (Hp), Gm allotypes (Gm), $\mathrm{Km}$ allotypes $(\mathrm{Km})$, group-specific component $(\mathrm{Gc}), \alpha_{1}$-antitrypsin $\left.(\mathrm{Pi})\right]$.

Statistical methods. The polymorphic alleles of D2S44, D17S30, and D1S57 were subdivided into 15, 28, and 5 non-overlapping groups, respectively (Yokoi et al., 1990a). The polymorphic alleles of MR24/1, 3'globin, Ha-ras, and mucin were also subdivided into $34,37,5$, and 10 non-overlapping groups of fragments, respectively (Yokoi et al., 1990b). Therefore, the allele frequency values were used directly for calculation. The size of the alleles was measured at 100-bp increment in MR24/1, 3'globin, D2S44, and D1S57 probings (partially 50-bp increment in D2S44) or 70-bp increments (D17S30). The database among Japanese population used in this study were summarized in our previous reports (Yokoi et al., 1990a, b) and schematically illustrated in Fig. 2. The paternity exclusion was calculated using the formula described for RFLP by Ito et al. (1985). The paternity index was calculated according to Garber and Morris (1983).

\section{RESULTS}

Summary of standard blood group markers of the family are shown in Table 1. The exclusion probability (EP) and paternity index (PI) were indicated in Table 3-1. The cumulative EP from standard blood group markers was 0.97 , which was calculated using gene frequency database among Japanese population. The cumulative PIs of IC-1, $-2,-3$, and -4 were $164.81,41.58,0.09$, and 36.44 , respectively (Table 3 ), and the combined probability of paternity equal to $0.9940,0.9765,0.0826$, and 0.9733 , respectively. 

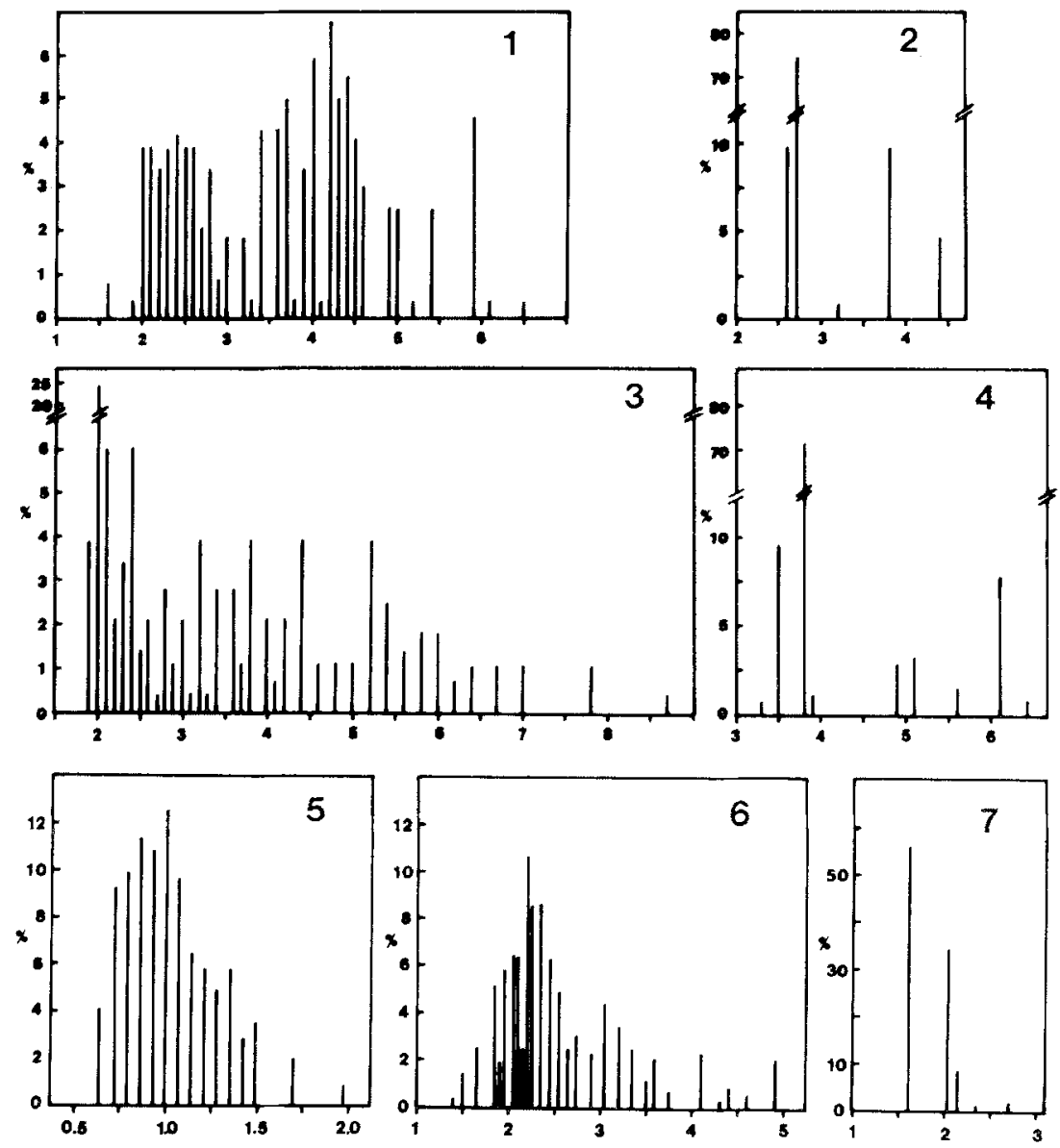

Fig. 2. Relative frequency of alleles according to their sizes among Japanese population. The combination of a probe and a restriction enzyme were as follows: 1, MR24/1 and HinfI; 2, Ha-ras and $P v u I I ; 3,3$ 'globin and $P v u I I ; 4$, Mucin and $P v u I I ; 5$, D2S44 and MspI; 6, D17S30 and MspI; 7, D1S57 and RsaI. The allele frequency and fragment length were indicated in percent and $\mathrm{kb}$, respectively.

Seven kinds of combination of DNA probes and restriction enzymes were applied to Southern blot analyses. Examples of the autoradiograms are shown in Figs. 3-A (HinfI enzyme and MR24/1 probe) and 3-B ( $P$ vull enzyme and Mucin probe). Size and frequency of each allele of the family with seven kinds of DNA probes were summarized in Table 2 and Fig. 2. In MR24/1-HinfI system analysis, for example (Fig. 3-1), the $3.9 \mathrm{~kb}$ and $2.3 \mathrm{~kb}$ alleles might be inherited to ICs from the alleged father. Allelic frequencies and its distributions among Japanese population were reported previously in detail from our laboratories (Yokoi et al., 1990a, b) and schematically illustrated in Fig. 2. The cumulative EP from DNA probes was $1-\left(9.3 \times 10^{-5}\right)$. The cumulative PIs of $\mathrm{IC}-1,-2,-3$, and -4 were 2,363.07, 
Table 1. Summary of blood group markers (phenotypes) typing of the family in dispute.

\begin{tabular}{|c|c|c|c|c|c|c|c|c|}
\hline & W & LC-1 & LC-2 & KM & IC-1 & IC-2 & IC-3 & IC-4 \\
\hline $\mathrm{ABO}$ & A & A & A & A & A & A & $\mathrm{O}$ & A \\
\hline MNSs & Ms & MNs & Ms & MNs & MNs & MNs & Ns & MNs \\
\hline $\mathrm{Rh}-\mathrm{Hr}$ & $\mathrm{CcDEe}$ & $\mathrm{CcDEe}$ & CcDEe & $\mathrm{CcDEe}$ & CcDEe & CCDee & CCDee & CCDee \\
\hline Duffy & $a+b-$ & $a+b-$ & $a+b-$ & $a+b-$ & $a+b-$ & $a+b-$ & $a+b-$ & $a+b-$ \\
\hline Kidd & $a+b+$ & $a+b+$ & $a-b+$ & $a-b+$ & $a+b+$ & $a+b+$ & $a+b+$ & $a-b+$ \\
\hline $\mathrm{P}_{1}$ & + & - & + & - & - & - & - & - \\
\hline $\mathrm{Hp}$ & $2-1$ & $2-2$ & $1-1$ & $2-1$ & $1-1$ & $2-2$ & $2-1$ & $2-1$ \\
\hline $\mathrm{Tf}$ & $\mathrm{C} 1-1$ & $\mathrm{Cl}-1$ & $\mathrm{C} 2-1$ & $\mathrm{Ci}-1$ & $\mathrm{C} 1-1$ & $\mathrm{C} 1-1$ & $\mathrm{C} 1-1$ & $\mathrm{C} 1-1$ \\
\hline $\mathrm{Gc}$ & $1 \mathrm{FS}$ & $1 \mathrm{~S}$ & $2-1 S$ & 2 & 2 & 2 & $2-1 S$ & 2 \\
\hline $\mathrm{Pi}$ & M1-1 & M1-1 & M1-1 & M2-1 & M1-1 & M1-1 & M1-1 & Mi-1 \\
\hline $\mathrm{Gm}$ & $\underset{\mathrm{b}^{3} \mathrm{st}}{\mathrm{ag}}$ & axg & $\underset{b^{3}}{\operatorname{axg}}$ & $\underset{\mathrm{b}^{3} \mathrm{st}}{\mathrm{ag}}$ & axg & axg & $\underset{\mathrm{b}^{3} \mathrm{st}}{\mathrm{ag}}$ & $\begin{array}{l}\mathrm{ag} \\
\mathrm{b}^{3} \mathrm{st}\end{array}$ \\
\hline $\mathrm{Km}$ & $1-$ & $1+$ & $1+$ & $1-$ & $1+$ & $1+$ & $1-$ & $1+$ \\
\hline $\mathrm{AcP}$ & $\mathrm{BA}$ & BA & BA & $\mathrm{BA}$ & $\mathrm{BA}$ & $\mathrm{BA}$ & $\mathrm{BA}$ & $\mathrm{BA}$ \\
\hline PGM & $1+1+$ & $1+2-$ & $1+1+$ & $2+2+$ & $2+2-$ & $2+2-$ & $2+1+$ & $2+-2-$ \\
\hline PGD & A & $\mathrm{A}$ & A & $\mathrm{AC}$ & $\mathrm{A}$ & $\mathrm{AC}$ & $\mathrm{AC}$ & $\mathrm{AC}$ \\
\hline EsD & $2-1$ & $2-1$ & $2-1$ & $1-1$ & $2-1$ & $2-1$ & $2-1$ & $2-1$ \\
\hline
\end{tabular}

Abbreviations: KM, kept mistress; W, wife; DF, deceased father; LC, legitimate child; IC, illegitimate child. Other abbreviations are mentioned in the text.

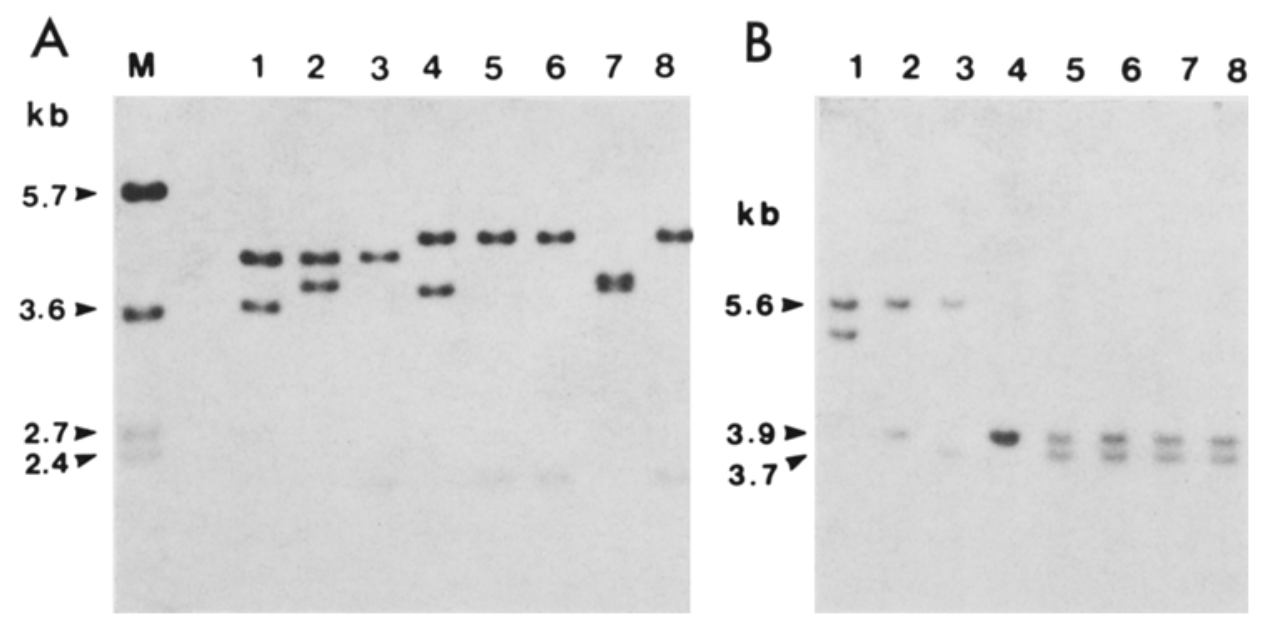

Fig. 3. Autoradiograms of Southern blots of the family in dispute are shown. The combinations of restriction enzyme and probe are as follows: A, HinfI-MR24/1; B, $P v u$ II-Mucin. 1, W; 2, LC-1; 3, LC-2; 4, KM; 5, IC-1; 6, IC-2; 7, IC-3; $8, \mathrm{IC}-4$. Allele size in $\mathrm{kb}$ and gene frequencies are indicated in Table 2 and Fig. 2. The arrowheads indicate the approximate size of the bands. The size was determined according to the method indicated in the text. 
T. YOKOI et al.

Table 2. Allele sizes observed with HVR DNA probes.

\begin{tabular}{ccccccccc}
\hline Probe/enzyme & W & LC-1 & LC-2 & KM & IC-1 & IC-2 & IC-3 & IC-4 \\
\cline { 2 - 8 } D2S44 & 4.10 & 4.10 & 4.10 & 3.05 & 2.10 & 3.05 & 3.05 & 2.25 \\
MspI & 2.10 & 2.25 & 2.25 & 2.10 & - & 2.10 & 2.25 & 2.10 \\
D17S30 & 0.79 & 0.79 & 0.79 & 0.86 & 0.79 & 0.86 & 0.79 & 0.86 \\
MspI & 0.65 & 0.65 & 0.65 & 0.72 & 0.72 & 0.79 & 0.72 & 0.79 \\
D1S57 & 1.60 & 1.60 & 1.60 & 2.05 & 2.05 & 1.60 & 1.60 & 1.60 \\
RsaI & - & - & - & 1.60 & - & - & - & - \\
MR24/1 & 4.3 & 4.3 & 4.3 & 4.60 & 4.6 & 4.6 & 3.9 & 4.6 \\
HinfI & 3.6 & 3.9 & 2.3 & 3.60 & 2.3 & 2.3 & 3.6 & 2.3 \\
3'globin & 2.1 & 2.1 & 3.6 & 4.4 & 4.0 & 4.4 & 4.4 & 4.4 \\
PvuII & - & 1.9 & 2.1 & 4.0 & 1.9 & 3.6 & 1.9 & 1.9 \\
Ha-ras & 2.7 & 2.7 & 2.7 & 4.4 & 2.7 & 4.4 & 4.4 & 4.4 \\
$P v u I I$ & 2.6 & - & 2.6 & - & - & 2.7 & - & 2.7 \\
Mucin & 5.6 & 5.6 & 5.6 & 3.9 & 3.9 & 3.9 & 3.9 & 3.9 \\
$P v u I I$ & 5.1 & 3.9 & 3.7 & - & 3.7 & 3.7 & 3.7 & 3.7 \\
\hline
\end{tabular}

Individuals showing one allele size are having homozygotic allele and two allele sizes having heterozygotic alleles.

Table 3-1. Summary of paternity indices and cumulative paternity indices of four illegitimate children investigated with standard blood group markers.

\begin{tabular}{|c|c|c|c|c|c|}
\hline & \multirow{2}{*}{$\begin{array}{l}\text { Exclusion } \\
\text { probability }\end{array}$} & \multicolumn{4}{|c|}{ Paternity index } \\
\hline & & IC-1 & $\mathrm{IC}-2$ & IC -3 & $\mathrm{IC}-4$ \\
\hline $\mathrm{ABO}$ & 0.19 & 1.22 & 1.22 & 0.95 & 1.22 \\
\hline MNSs & 0.24 & 1.06 & 1.06 & 1.10 & 1.06 \\
\hline $\mathrm{Rh}-\mathrm{Hr}$ & 0.24 & 1.06 & 1.06 & 1.06 & 1. 06 \\
\hline Duffy & 0.08 & 1.08 & 1.08 & 1.08 & 1.08 \\
\hline Kidd & 0.18 & 0.33 & 0.33 & 0.33 & 1.60 \\
\hline$P_{1}$ & 0.08 & 1.08 & 1.08 & 1.08 & 1.08 \\
\hline Hp & 0.16 & 2.35 & 0.64 & 1.00 & 1.00 \\
\hline $\mathrm{Tf}$ & 0.16 & 0.67 & 0.67 & 0.67 & 0.67 \\
\hline $\mathrm{Gc}$ & 0.38 & 1.98 & 1.98 & 2.02 & 1.98 \\
\hline $\mathrm{Pi}$ & 0.22 & 1.25 & 1.25 & 1.25 & 1.25 \\
\hline $\mathrm{Gm}$ & 0.41 & 3.75 & 3.75 & 0.43 & 0.43 \\
\hline $\mathrm{Km}$ & 0.17 & 2.42 & 2.42 & 0.38 & 2. 42 \\
\hline $\mathrm{AcP}$ & 0.14 & 1.00 & 1.00 & 1.00 & 1.00 \\
\hline PGM & 0.26 & 8.30 & 8.30 & 0.77 & 8.30 \\
\hline PGD & 0.07 & 1.07 & 1.00 & 1.00 & 1.00 \\
\hline EsD & 0.18 & 1.00 & 1.00 & 1.00 & 1.00 \\
\hline Cumulative & 0.97 & 164.81 & 41.58 & 0.09 & 36.44 \\
\hline
\end{tabular}


Table 3-2. Summary of paternity indices and cumulative paternity indices of four illegitimate children investigated with hypervariable DNA probes.

\begin{tabular}{|c|c|c|c|c|c|c|c|}
\hline \multirow{2}{*}{ Probe } & \multirow{2}{*}{$\begin{array}{l}\text { Exclusion } \\
\text { probability }\end{array}$} & \multirow{2}{*}{$\begin{array}{l}\text { No. of } \\
\text { alleles }\end{array}$} & \multirow{2}{*}{$\begin{array}{l}\text { Hetero- } \\
\text { zygosity }\end{array}$} & \multicolumn{4}{|c|}{ Paternity index } \\
\hline & & & & IC-1 & IC-2 & IC-3 & IC-4 \\
\hline D2S44 & 0.89 & 28 & 0.944 & 0.46 & 0.46 & 6.74 & 6.74 \\
\hline D17S30 & 0.83 & 15 & 0.912 & 4.46 & 4. 46 & 4.46 & 4.46 \\
\hline D1S57 & 0.30 & 5 & 0.569 & 1.08 & 1.61 & 1.61 & 1.61 \\
\hline $\mathrm{MR} 24 / 1$ & 0.92 & 34 & 0.959 & 13.16 & 13.16 & 14.71 & 14.71 \\
\hline 3'globin & 0.84 & 37 & 0.917 & 12.82 & 17.86 & 12.82 & 12.82 \\
\hline Ha-ras & 0.24 & 5 & 0.419 & 1.20 & 1. 15 & 1. 21 & 1. 15 \\
\hline Mucin & 0.29 & 10 & 0.496 & 5.22 & 5.22 & 5.22 & 5.22 \\
\hline Cumulat & $\left.3 \times 10^{-5}\right)$ & & & $2,363.07$ & $4,684.74$ & 677.72 & 994.26 \\
\hline
\end{tabular}

$4,684.74,57,677.72$, and 54,994.26, respectively (Table 3 ), and combine dprobability of paternity equal to $0.9996,0.9998,0.99998$, and 0.99998 , respectively. The data were $14,113,640,864$, and 1,509 times higher than the indices from standard blood group markers.

\section{DISCUSSION}

Recently we had a paternity test in which the putative father was deceased and unavailable for the test. The two legitimate children and their mother and the four illegitimate children and their mother (the deceased's kept mistress) were available for analysis. The cumulative PI of four illegitimate children (IC) from 16 kinds of standard blood group markers were $165,42,0.09$, and 36 , respectively. These data are obviously not high, especially with the third IC. Therefore, DNA analyses were ordered by the court. The PI of Tf gave the score which let down the cumulative score of all four ICs. Lewis and saliva types were not measured due to unestablished mode of inheritance among Japanese population.

Hypervariable DNA polymorphisms has been widely applied, in individual identification (Jeffreys et al., 1985b; Gill et al., 1985; Giusti et al., 1986), and in paternity suits (Jeffreys et al., 1985a; Baird et al., 1986; Allen et al., 1989). Most of them are multi-locus probes that recognize several loci under the conditions of reduced stringency. The traditional statistical analyses of paternity and probability of matching are not suitable to apply to the results of multi-locus probes due to the undefined chromosome location and is subject to several assumptions as mentioned by Odelberg et al. (1988). In the present study, seven single-locus highly polymorphic DNA probes, which lie on different chromosomes except DIS57 locus on $1 p$ and mucin locus on 1q21, was used.

We adopted the indication of fragment size in 100-bp increment (MR24/1, 3'globin, D2S44, and D1S57) or 70-bp increment (D17S30). For example, the 
alleles detected by D2S44 probing have been grouped into 28 size classes among Japanese population, but these categories do not represent individual alleles. The recognition of single repeat of the core sequence (30 base pair, Nakamura et al., 1987) will be beyond the capability of agarose gel electrophoresis methods. This probe, D2S44, has theoretically over 110 different repeat units among Japanese population, but this way of increment indication might be a conservative approach for standardization of the fragment size.

The 3'globin probe was reported to be used for paternity test among the population in the United States by Allen et al. (1989), and PI was calculated as between three to twenty-five in two generation family studies. In the present study, PI was 12.82 (IC-1, -3, -4) and 17.86 (IC-2) with 3 'globin probing. The distribution of allelic size differs among races, which was reported with some VNTR probes in American populations (Balazs et al., 1989).

A family case with a deceased father was reported by Boonlayangoor (1989). DNA analyses were not done in this case. The cumulative PI was 7.82 from 15 kinds of blood group markers and 630.32 including HLA system. In the conclusion of the present study, four of seven probes, D2S44, D17SA30, MR24/1, and $3^{\prime}$ globin gave over 0.8 of EP which were recommendable for efficient paternity test in Japanese population. With these four probes, the cumulative EP should be 0.9998 and the cumulative PIs in this case 346.1 (IC-1) to 5,668.9 (IC-3 and -4).

Jeffreys et al. (1988) reported that some 'fingerprinting' probe demonstrated a mutation rate of $5.2 \%$ per gamete. On the other hand, in more than 200 cases examined with 3 'globin no mutation has been observed (Allen et al., 1989). Wolff et al. (1988) mentioned that the mutation rate of pYNZ22 loci was $0.2 \%$. The hypervariable loci of single-locus recognition have been reported to be more stable inherited than multi-locus probe (Odelberg et al., 1989), so these may be a more practical approach for parentage testing. In the cases of parental negation with hypervariable DNA probes, it should be confirmed with other probes locating on the other chromosome.

The probes, MR24/1, 3'globin, Ha-ras, and Mucin, are available from Amersham U.K., and the others, D2S44, D17S30, and D1S57, from the ATCC, U.S.A. or from the JCRB Gene Bank, Japan and from Promega, U.S.A. They can be used almost without constraint of patents. On the other hand, the minisatellite DNA probes developed by Jeffreys were restricted for research purposes only. As pointed out by Yokoi et al. (1990a, b) and Odelberg et al. (1989), the combination of single-locus DNA polymorphisms is considered to be informative enough not only for parentage test but also for forensic, anthropological and other human genetic purposes.

Acknowledgments This study was supported in part by the Takeda Life Science Foundation and the Ministry of Education, Science and Culture of Japan. 


\section{REFERENCES}

Allen, R.W., Bliss, B. and Pearson, A. 1989. Characteristics of a DNA probe (pa3'HVR) when used for paternity testing. Transfusion 29: 477-485.

Baird, M., Balazs, I., Giusti, A., Miyazaki, L., Nicholas, L., Wexler, K., Kanter, E., Glassberg, J., Allen, F., Rubinstein, P. and Sussmann, L. 1986. Allele frequency distribution of two highly polymorphic DNA sequences in three ethnic groups and its application to the determination of paternity. Am. J. Hum. Genet. 39: 489-501.

Balazs, I., Baird, M., Clyne, M. and Maeda, E. 1989. Human population genetic studies of five hypervariable DNA loci. Am. J. Hum. Genet. 44: 182-190.

Boonlayangoor, P.W. 1989. True paternity or exclusion: Analysis in the case of a deceased party. J. Forens. Sci. 34: 703-707.

Capon, D.J., Chen, E.Y., Levinson, A.D., Seeburg, P.H. and Goeddel, D.V. 1983. Complete nucleotide sequences of the T24 human bladder carcinoma oncogene and its normal homologue. Nature 302: 33-37.

Garber, R.A. and Morris, J.W. 1983. General equations for the average power of exclusion for genetic systems of n codominant alleles in one-parent and no-parent cases of desputed parentage. In Inclusion Probabilities in Parentage Testing, Walker, R.H., ed., American Association of Blood Banks, Arlington, Virginia, pp. 277-280.

Gendler, S.J., Burchell, J.M., Duhig, T., Lamport, D., White, R., Parker, M. and Taylor-Paradimitriou, J. 1987. Cloning of partial cDNA encoding differentiation and tumor-associated mucin glycoproteins expressed by human mammary epithelium. Proc. Natl. Acad. Sci. U.S.A. 84: $6060-6064$.

Gill, P., Jeffreys, A.J. and Werrett, D.J. 1985. Forensic application of DNA 'fingerprints.' Nature 318: $577-579$.

Giusti, A., Baird, M., Pasquale, S., Balazs, I. and Glassberg, J. 1986. Application of deoxyribonucleic acid (DNA) polymorphisms to the analysis of DNA recovered from sperm. $J$. Forens. Sci. 31: 409-417.

Higgs, R.D., Goodbourn, S.E.Y., Wainscoat, J.S., Clegg, J.B. and Weatherall, D.J. 1981. Highly variable regions of DNA flank the human alpha globin genes. Nucleic Acids Res. 9: 42134224.

Ito, H., Yasuda, N. and Matsumoto, H. 1985. The probability of parentage exclusion based on restriction fragment length polymorphisms. Jpn. J. Human Genet. 30: 261-269.

Jeffreys, A.J., Wilson, V. and Thein, S.L. 1985a. Hypervariable 'minisatellite' regions in human DNA. Nature 314: 67-73.

Jeffreys, A.J., Brookfield, J.E.Y. and Semenoff, R. 1985b. Positive identification of an immigration test-case using human DNA fingerprints. Nature 317: 818-819.

Jeffreys, A.J., Royle, N.J., Wilson, V. and Wong, Z. 1988. Spontaneous mutation rates to new length alleles at tandem repetitive hypervariable loci in human DNA. Nature 332: 278-281.

Maniatis, T., Fritsch, E.F. and Sambrook, J. 1982. Molecular Cloning. A laboratory manual. Cold Spring Harbor Lab., Cold Spring Harbor, New York.

Nakamura, Y., Leppert, M., O'Connell, P., Woff, R., Holm, T., Culver, M., Martin, C., Fujimoto, E., Hoff, M., Kumlin, E. and White R. 1987. Variable number of tandem repeat (VNTR) markers for human gene mapping. Science 235: 1616-1622.

Nakamura, Y., Lathrop, M., O’Connell, P., Leppert, M., Barker, D., Wright, E., Skolnick, M., Kondoleon, S., Litt, M., Lalouel, J.M. and White, R. 1988a. A mapped set of DNA marker for human chromosome 17. Genomics 2: 302-309.

Nakamura, Y., Lathrop, M., O'Connell, P., Leppert, M., Lalouel, J.M. and White, R. 1988b. A mapped set of DNA markers for human chromosome 15. Genomics 3: 342-346.

Odelberg, S.J., Demers, D.B., Westin, E.H. and Hossaini, A.A. 1988. Establishing paternity using 
minisatellite DNA probes when the putative father is unavailable for testing. J. Forens. Sci. 33: $921-928$.

Odelberg, S.J., Plaetke, R., Eldridge, J.R., Ballard, L., O’Connell, P., Nakamura, Y., Leppert, M., Lalouel, J.M. and White, R. 1989. Characterization of eight VNTR loci by agarose gel electrophoresis. Genomics 5: 915-924.

Wolff, R.K., Nakamura, Y. and White, R. 1988. Molecular characterization of a spontaneously generated new allele at a VNTR locus: No exchange of flanking DNA sequence. Genomics 3: 347-351.

Yokoi, T., Nata, M., Odaira, T. and Sagisaka, K. 1990a. Hypervariable polymorphic VNTR loci for parentage testing and individual identification. $J_{p n} . J$. Human Genet. 35: 179-188.

Yokoi, T., Nata, M., Odaira, T. and Sagisaka, K. 1990b. Hypervariable regions of DNA for parentage testing and individual identification. $Z$. Rechtsmed. $103: 487-497$. 